\title{
The inhibition of in-vitro ovulation from follicles of the teleost, Oryzias latipes, by cytochalasin B
}

\author{
P. C. Schroeder and Paula Pendergrass* \\ Department of Zoology, Washington State University, \\ Pullman, Washington 99163, U.S.A.
}

\begin{abstract}
Summary. Ovulation in vitro from isolated follicles of the teleost fish, Oryzias latipes (the medaka), is completely and reversibly inhibited by cytochalasin B. Ultrastructural examination of treated follicles shows no morphological changes in microfilament populations within the follicle, but shows an increasing number of small holes in the basal lamina between the epithelial (thecal) cells and the follicle cells with increasing duration of exposure. It is suggested that these correlate with the decreasing success of ovulation after drug removal after longer incubations with cytochalasin B.
\end{abstract}

\section{Introduction}

In spite of a large body of literature dealing with the ultrastructure and chemical control of ovulation in vertebrates, there is little understanding of the mechanism(s) responsible for oocyte extrusion in lower vertebrates. Most current theories on the mechanism of vertebrate ovulation include the view that enzymatic destruction of follicular tissue precedes application of a force which tears the follicle and represents the step during which the oocyte is extruded (Epsey \& Lipner, 1965; Anderson \& Yatvin, 1970). In mammals, accumulation of fluid within the follicle, which distends the follicle rather than increasing the intrafollicular fluid pressure, is thought to provide this force (Lipner, 1973; Bjersing \& Cajander, 1974), but a role for intrafollicular contraction has not been ruled out. There has been little investigation of the origin of this force in lower vertebrates, whose follicles lack a fluid-filled antrum. The squeezing of the oocyte from the follicle during ovulation in lower vertebrates does not appear to be dependent upon contractions of ovarian smooth muscle: follicles isolated from frog (Rugh, 1935) and fish (Hirose, 1971) ovaries are capable of ovulating by themselves in vitro.

Schroeder (1973) found that hormone-stimulated ovulation from pieces of frog (Rana and Hyla) ovary in vitro was inhibited by the drug cytochalasin $B$, which has been demonstrated to inhibit both muscular (Bereiter-Hahn \& Viehmann, 1972) and microfilamentous (Wessels et al., 1971) contractile systems. Schroeder postulated that a microfilamentous contractile system, probably located in the follicle cells, functioned in ovulation in the frog.

After study of the ultrastructure of the follicular envelope and the constriction of the oocyte of Oryzias during ovulation in vitro, we concluded that, in this species, the discontinuous patches of follicular cells could not be the source of the constricting force (Pendergrass \& Schroeder, 1976). Instead, we suggested that the bundles of 50-70 $\AA$ microfilaments which are abundant in the thecal layers after incubation for about $10 \mathrm{hr}$ are involved in oocyte extrusion. We therefore investigated the effects of cytochalasin B on ovulation in vitro and on the thecal cell microfilaments in the teleost fish, Oryzias latipes (medaka).

\section{Materials and Methods}

Fish were maintained and brought into breeding condition as described previously (Pendergrass \& Schroeder, 1976); the lighting regimen was $18 \mathrm{hr}$ light/24 hr.

* Present address: Department of Biology, Texas Woman's University, Texas Medical Center, Houston, Texas 77025, U.S.A. 
Ovaries from fish killed $9 \mathrm{hr}$ before first light were placed into Medium-199 (Grand Island Biological Co.) at room temperature. Oocytes with intact follicular envelopes were dissected from several ovaries and those $\geqslant 0.8 \mathrm{~mm}$ in diameter were pooled to get a sufficiently large sample. The intact follicles were placed in various media as indicated in Table 1.

Table 1. The effect on ovulation of medaka follicles of incubation for $15 \mathrm{hr}$ in various media

\begin{tabular}{|c|c|c|c|c|c|}
\hline \multicolumn{4}{|c|}{ Incubation medium (per ml) } & \multirow[b]{2}{*}{$\begin{array}{l}\text { No. of } \\
\text { follicles }\end{array}$} & \multirow[b]{2}{*}{$\begin{array}{c}\% \\
\text { ovulating }\end{array}$} \\
\hline M-199 & DMSO & $\begin{array}{l}\text { Hydrocortisone } \\
\text { acetate* }\end{array}$ & Cytochalasin $\mathrm{B} \dagger$ & & \\
\hline 1. $5 \mathrm{ml}$ & 1,3 or $5 \mu l$ & - & - & 100 & 50 \\
\hline 2. $5 \mathrm{ml}$ & 1,3 or $5 \mu 1$ & $2 \mu \mathrm{g}$ & - & 100 & 88 \\
\hline 3. $5 \mathrm{ml}$ & $1 \mu \mathrm{I}$ & $2 \mu \mathrm{g}$ & $1 \mu \mathrm{g}$ & 33 & 0 \\
\hline 4. $5 \mathrm{mI}$ & $3 \mu \mathrm{l}$ & $2 \mu \mathrm{g}$ & $3 \mu \mathrm{g}$ & 33 & 0 \\
\hline 5. $5 \mathrm{ml}$ & $5 \mu l$ & $2 \mu \mathrm{g}$ & $5 \mu \mathrm{g}$ & 33 & 0 \\
\hline
\end{tabular}

* Merck, Sharpe \& Dohme.

$\dagger$ A gift of S. B. Carter, Imperial Chemical Industries, Ltd, used as a stock solution of $1 \mathrm{mg} / \mathrm{ml}$ in dimethylsulphoxide (DMSO).

Follicles were incubated for $15 \mathrm{hr}$, examined at a magnification of $\times 20$ and scored as either ovulated or unovulated depending on the visibility of chorionic attaching filaments and the absence of the follicular layers around the oocyte. To determine reversibility, 100 follicles incubated for 5,10 or $15 \mathrm{hr}$ in $1 \mu \mathrm{g}$ cytochalasin $\mathrm{B} / \mathrm{ml}$ were washed three times and placed into fresh $\mathrm{M}-199+$ hydrocortisone acetate $(2 \mu \mathrm{g} / \mathrm{ml})$, without DMSO. Follicles washed after 5 and $10 \mathrm{hr}$ were examined for signs of ovulation at $15 \mathrm{hr}$; those washed at $15 \mathrm{hr}$ were examined at $20 \mathrm{hr}$. A few $(<5 \%)$ of the oocytes in each group did not undergo germinal vesicle breakdown; these were not included in the scoring.

Electron microscope preparation. Oocytes which had been incubated in M-199 with $1 \mu 1 \mathrm{DMSO} / \mathrm{ml}$ alone, with hormone, and with $2 \mu \mathrm{g}$ hormone $+1 \mu \mathrm{g}$ cytochalasin $\mathrm{B} / \mathrm{ml}$ were fixed for electron microscope examination after $0,5,10$ or $15 \mathrm{hr}$ of incubation using the cacodylate buffer fixative previously described (Pendergrass \& Schroeder, 1976). Silver sections were cut with a diamond knife, stained with methanolic uranyl acetate and lead citrate (Reynolds, 1963) and examined with an Hitachi HS-8 transmission electron microscope. An ocular micrometer calibrated against a stage micrometer was used to measure diameters of microfilaments on negatives exposed at a magnification of $\times 21,000$.

\section{Ovulation}

\section{Results}

The effects of addition of hydrocortisone and cytochalasin B to the medium on ovulation in vitro are shown in Table 1. The presence of hydrocortisone in the medium improved the follicular response, while no follicle incubated in the presence of cytochalasin B ovulated. Oocytes exposed to the hormone and drug almost always exhibited germinal vesicle breakdown despite the absence of ovulation. In the reversibility test, 85,60 and $30 \%$ of the follicles (30/group) incubated for 5, 10 or $15 \mathrm{hr}$ respectively before washing ovulated successfully.

Ovulation usually occurs shortly after $10 \mathrm{hr}$ of incubation; follicles treated with cytochalasin B and returned to drug-free, hormone-containing medium after 5 or $10 \mathrm{hr}$ usually ovulated at $10 \mathrm{hr}$ or shortly thereafter (within $30 \mathrm{~min}$ in the latter group); those incubated for $15 \mathrm{hr}$ ovulated at about $19 \mathrm{hr}$.

\section{EXPLANATION OF PLATE 1}

Ovarian follicles of the medaka : bl, basal lamina; $f$, filament bundle; fc, follicle cell; tc, thecal cell.

Fig. 1. Periphery of a follicle incubated for $10 \mathrm{hr}$ in a medium containing hydrocortisone and cytochalasin B $(1 \mu \mathrm{g} / \mathrm{ml})$. The thecal cell filaments remain intact although ovulation is inhibited. $\times 73,500$. Inset: Damaged basal lamina in similarly treated follicle. $\times 60,800$.

Fig. 2. Periphery of an unovulated follicle incubated for $10 \mathrm{hr}$ in cytochalasin $B(1 \mu \mathrm{g} / \mathrm{ml})$ and then placed for $5 \mathrm{hr}$ in medium containing hydrocortisone. Thecal cell filaments are present and prominent. $\times 88,200$. 

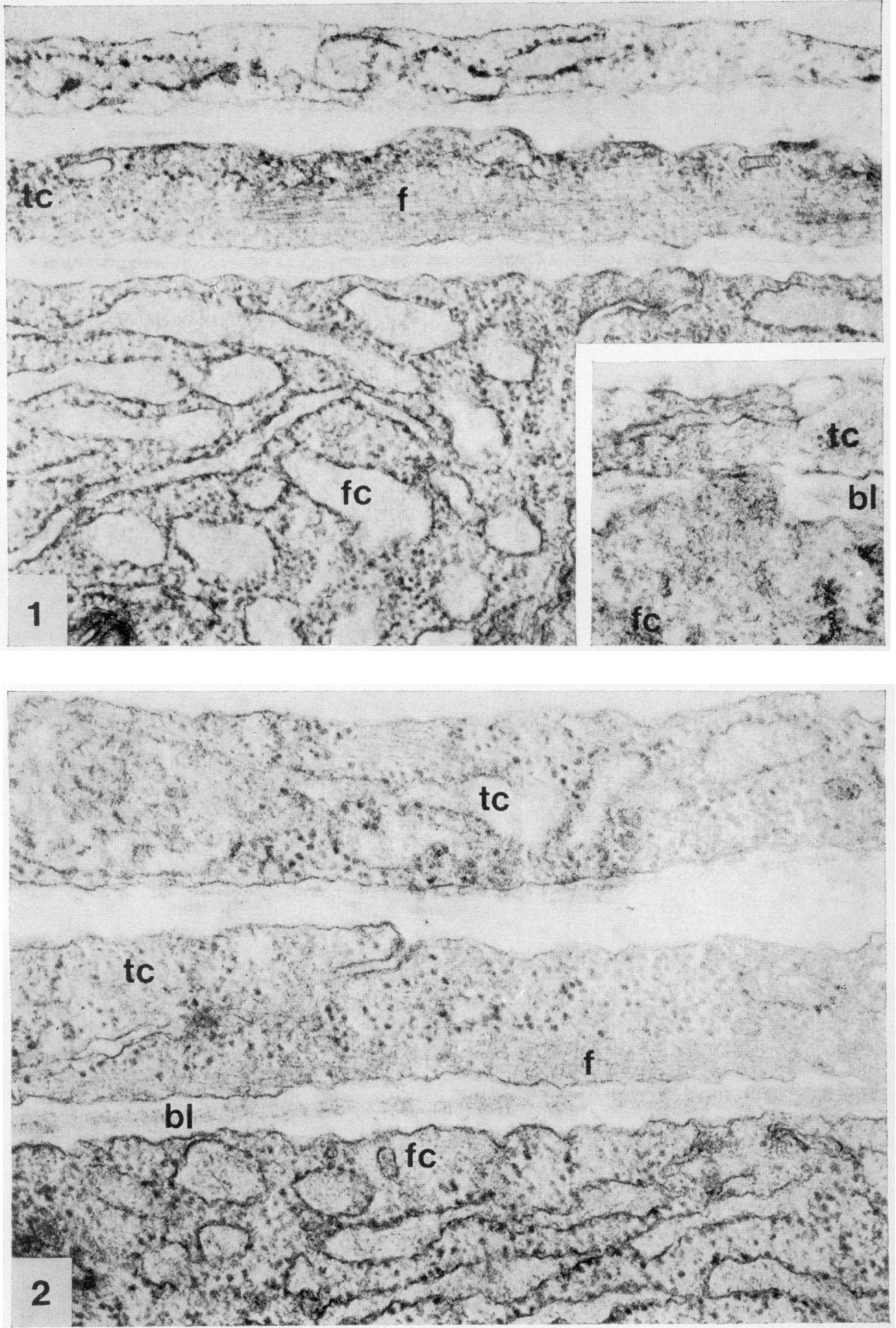

(Facing p. 328) 


\section{PLATE 1}

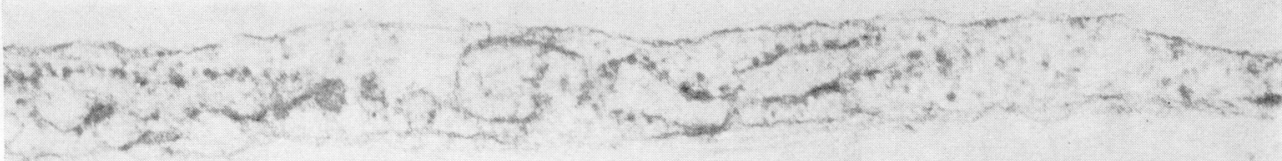

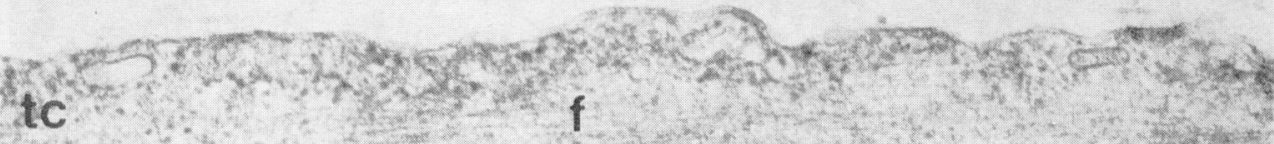
Q.

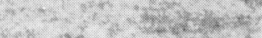
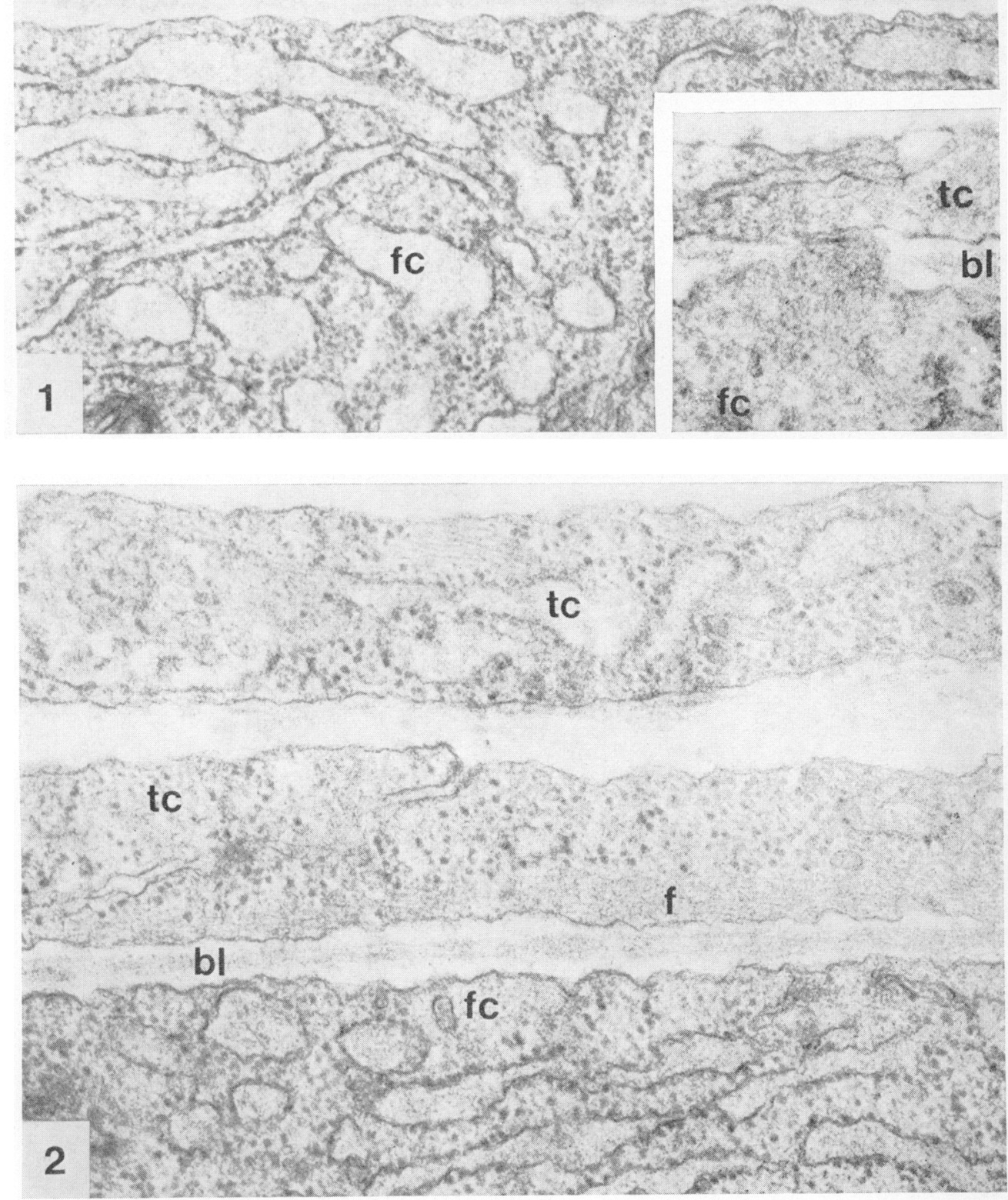

(Facing p. 328) 


\section{Ultrastructural observations}

Electron micrographs of follicular envelopes incubated for 5,10 or $15 \mathrm{hr}$ with or without cytochalasin B exhibited only one difference: follicles incubated for 10 (Pl. 1, Fig. 1) or more hours in cytochalasin B-containing medium had gaps in the basal lamina which were more frequent after the longer incubation. It is possible that the increasing frequency of these gaps with increasing duration of drug treatment led to the decreasing success of subsequent ovulation observed upon return to a drug-free medium. Follicles removed from cytochalasin B-containing medium before gaps appeared in the basal lamina and allowed to ovulate were ultrastructurally similar to untreated cells (Pl. 1, Fig. 2).

Despite the frequency with which cytochalasin B has been reported to affect microfilaments morphologically, the microfilaments in the thecal cells of Oryzias were similar to, and as extensive as, those found in control follicles that are expected to ovulate (Pendergrass \& Schroeder, 1976).

\section{Discussion}

The complete inhibition by cytochalasin B of ovulation of Oryzias follicles invitroagrees with previous reports from this laboratory on the inhibition of ovulation in amphibians (Schroeder, 1973) and cell movements related to spawning in the starfish (Schroeder, 1971), but contrasts with the report of Jalabert \& Szollosi (1975), who found that 1 or $5 \mu \mathrm{g}$ cytochalasin B/ml did not completely inhibit prostaglandin-induced ovulation in vitro in the rainbow trout (Salmo gairdnerii). However, the two fish species apparently differ in the relative timing of germinal vesicle breakdown and ovulation: in the trout, oocytes were not removed from the female until $12-24 \mathrm{hr}$ after germinal vesicle breakdown, and ovulation had not then taken place, while germinal vesicle breakdown occurs $4 \mathrm{hr}$ before ovulation in the medaka (Yamauchi \& Yamamoto, 1973). The follicular tissue of the trout, therefore, had probably been exposed to the normal preovulatory endocrine environment for a considerable period, allowing some of the preovulatory events in the follicle to occur in vivo before addition of cytochalasin $B$ in vitro. In the medaka experiments, however, the drug probably operated throughout the postulated period of morphogenesis of myoepithelial cells in the theca (Pendergrass \& Schroeder, 1976).

The effects of cytochalasin $B$ are multiple and a complete picture of the action of the drug on cells has not yet emerged. The affinity of $\left[{ }^{3} \mathrm{H}\right]$ cytochalasin $\mathrm{B}$ for actin isolated from various sources is relatively low (Lin \& Spudich, 1974), although a direct effect upon actin filaments in vitro has been reported (Spudich, 1972). Cytoplasmic filaments, thought to represent actin, often appear to break down in the presence of the drug (Wessells et al., 1971), but in many cases only the arrangement of the filaments is altered (see Goldman, 1972; Cloney, 1972; Messier \& Auclair, 1972; Mak, Trier, Serflippi \& Donaldson, 1974). Since there is no other apparent contractile system within the Oryzias follicle, we conclude that the filament system found in the thecal epithelial cells must represent the contractile system whose function is inhibited by cytochalasin $B$, despite the unchanged ultrastructure. Spudich (1972) found that the addition of the troponin-tropomyosin complex prevented the disintegration of isolated actin filaments observed with cytochalasin B. The troponin-tropomyosin complex has been found in the smooth muscle of chicken gizzards (Ebashi, Toyo-Oka \& Nonomura, 1975), brain (Puszkin \& Kochwa, 1974) and platelets (Puszkin, Kochwa \& Rosenfield, 1975) and is thought to be present in smooth muscle generally (Weber \& Bremel, 1971). The complex may therefore be present in the Oryzias follicle and serve to stabilize the filaments.

The presence of an intact but inhibited contractile system in cytochalasin-treated follicles is also suggested by the speed with which ovulation occurs after removal of the drug: some follicles completed ovulation within 2 min of washing.

The filament arrangement and density in the thecal cells in Oryzias is more similar to that in smooth muscle than to that in most of the non-muscular filament systems which have been studied with cytochalasin $B$. However, the medaka thecal cells lack several of the cytological features characteristic of smooth muscle (Gabella, 1973), e.g. the caveolae (membrane vesicles along the plasmalemma of the cell) and the dense patches in the filament mass. An effect of cytochalasin B on smooth muscle 
has been reported by Bereiter-Hahn \& Viehmann (1972) who found that $0 \cdot 3 \mathrm{~mm}$ inhibited ATPstimulated contraction of glycerinated gut segments of the swordtail, Platypoecilus helleri, although the inhibition in this teleost preparation was not complete. Wessells et al. (1971) reported that the drug slowly inhibited the contraction of embryonic mouse gut: this effect was reversible, but only after a long delay. We have not seen any reports describing the ultrastructure of cytochalasin Btreated smooth muscle cells and cannot therefore say whether the medaka thecal filaments are similar in this respect also.

Most of this research was undertaken in partial fulfillment of the $\mathrm{Ph}$.D. requirements for Washington State University (P.P). It was supported by the Electron Microscope Center at Washington State University, by NIH Grant HDO7194, by a grant-in-aid to research from the Society of Sigma $\mathrm{Xi}$ and by departmental research funds from Texas Woman's University.

\section{References}

Anderson, J.W. \& Yatvin, M.B. (1970) Metabolic and ultrastructural changes in the frog ovarian follicle in response to pituitary stimulation. $J$. Cell Biol. 46, 491-504.

Bereiter-HahN, J. VON \& ViehmanN, W. (1972) Wechselwirkung von Cytochalasin B mit Aktomyosin. Naturwissenschaften 59, 513-514.

Bjersing, L. \& Cajander, S. (1974) Ovulation and mechanism of follicle rupture. VI. Ultrastructure of theca interna and the inner vascular network surrounding rabbit Graafian follicles prior to induced ovulation. Cell Tissue Res. 149, 287-300.

Cloney, R.A. (1972) Cytoplasmic filaments and morphogenesis: effects of cytochalasin B on contractile epidermal cells. Z. Zellforsch. mikrosk. Ant. 132, 167192.

Ebashi, S., Toyo-OKa, T. \& NonOmura, Y. (1975) Gizzard Troponin. J. Biochem. (Tokyo) 78, 859-861.

ESPEY, L. \& LIPNER, H. (1965) Enzyme-induced rupture of rabbit Graafian follicle. Am. J. Physiol. 298, 208213.

GABELlA, G. (1973) Fine structure of smooth muscle. Phil. Trans. $R$. Soc. 265B, 7-16.

Goldman, R.D. (1972) The effects of cytochalasin B on the microfilaments of baby hamster kidney (BHK-21) cells. J. Cell Biol. 52, 246-255.

Hirose, K. (1971) Biological study on ovulation in vitro of fish. I. Effects of pituitary and chorionic gonadotropins on ovulation in vitro of Medaka, Oryzias latipes. Bull. Jap. Soc. scient. Fish. 37, 585592.

JALABERT, B. \& Szollost, D. (1975) In vitro ovulation of trout oocytes: effects of prostaglandins on smoothmuscle-like cells of the theca. Prostaglandins 9, 765778.

LIN, S. \& Spudich, J.A. (1974) Biochemical studies on the mode of action of cytochalasin B. J. biol. Chem. 249, 5778-5783.

LIPNER, H. (1973) Mechanism of mammalian ovulation. In Handbook of Physiology, Sect. 7, Endocrinology II, Part 1, pp. 409-457. Eds R.O. Greep \& E.B. Eastwood. American Physiological Society, Washington, D.C.

Mak, K.B., Trier, J.S., Serflippi, D. \& Donaldson,
R.M. (1974) Resistance of adult mammalian intestinal mucosa to cytochalasin B. Expl Cell Res. 86, 325-332.

Messier, P.-E. \& Auclair, C. (1972) Effect of cytochalasin $B$ on interkinetic nuclear migration in the chick embryo. Devl Biol. 36, 218-223.

Pendergrass, P.B. \& Schroeder, P.C. (1976) The ultrastructure of the thecal cell of the teleost, Oryzias latipes, during ovulation in vitro. J. Reprod. Fert. 47, 229-233.

Puszkin, S. \& Kochwa, S. (1974) Regulation of neurotransmitter release by a complex of actin with relaxing protein isolated from rat brain synaptosomes. J. biol. Chem. 249, 7711-7714.

Puszkin, S., Kochwa, S. \& Rosenfield, R. (1975) Regulatory complex of human platelet actomyosin. J. Cell Biol. 67, 346a.

Reynolds, E. (1963) The use of lead citrate at high $\mathrm{pH}$ as an electron opaque stain in electron microscopy. J. Cell Biol. 17, 208-212.

Rugh, R. (1935) Ovulation in the frog. Il. Follicular rupture to fertilization. J. exp. Zool. 71, 163-193.

SCHROEDER, P.C. (1971) Active contraction of starfish oocyte follicle cells after treatment with 1-methyl adenine. Naturwissenschaften 58, 270-271.

SCHROEDER, P.C. (1973) The inhibition of amphibian ovulation in vitro by cytochalasin B. Experientia 29, 617-618.

SPUDICH, J.A. (1972) Effects of cytochalasin B on actin filaments. Cold Spring Harb. Symp. quant. Biol. 37, 585-595.

Weber, A. \& BREMEL, R. (1971) Regulation of contraction and relaxation in the myofibril. In Contractility of Muscle Cells and Related Processes, pp. 37-53. Ed. R.J. Podolsky. Soc. Gen. Physiologists Symposium, Prentice Hall, Englewood Cliffs, New Jersey.

Wessells, N. Spooner, B., Ash, F., Bradley, M., Luduena, M., Taylor, E., Wrenn, J. \& Yamada, K. (1971) Microfilaments in cellular and developmental processes. Science, N.Y. 171, 135-143.

YAMAUCHI, K. \& YАMAMOTO, K. (1973) In vitro maturation of the oocytes of the medaka Oryzias latipes. Annotnes zool. jap. 46, 144-153. 